\title{
Depth Dependent Relationships between Temperature and Ocean Heterotrophic Prokaryotic Production
}

OPEN ACCESS

Edited by:

James Cotner,

University of Minnesota, USA

Reviewed by:

Thad Scott

University of Arkansas, USA

Edward Hall,

Colorado State University, USA

*Correspondence:

Christian Lonborg clonborg@gmail.com

Specialty section:

This article was submitted to

Aquatic Microbiology,

a section of the journal

Frontiers in Marine Science

Received: 08 December 2015

Accepted: 20 May 2016

Published: 07 June 2016

Citation:

Lonborg C, Cuevas LA, Reinthaler T, Herndl GJ, Gasol JM, Morán XAG,

Bates NR and Álvarez-Salgado XA

(2016) Depth Dependent

Relationships between Temperature and Ocean Heterotrophic Prokaryotic

Production. Front. Mar. Sci. 3:90.

doi: 10.3389/fmars.2016.00090

\begin{abstract}
Christian Lønborg ${ }^{1 *}$, L. Antonio Cuevas ${ }^{2}$, Thomas Reinthaler ${ }^{3}$, Gerhard J. Herndl ${ }^{3,4}$, Josep M. Gasol ${ }^{5}$, Xosé Anxelu G. Morán ${ }^{6}$, Nicholas R. Bates ${ }^{7}$ and Xosé A. Álvarez-Salgado ${ }^{8}$

${ }^{1}$ Australian Institute of Marine Science, Townsville, QLD, Australia, ${ }^{2}$ Environmental Science Faculty, EULA-University of Concepción, Concepción, Chile, ${ }^{3}$ Department of Limnology and Bio-Oceanography, Center of Ecology, University of Vienna, Vienna, Austria, ${ }^{4}$ Department of Biological Oceanography, Royal Netherlands Institute for Sea Research, AB Den Burg, Netherlands, ${ }^{5}$ ICM-CSIC, Institut de Ciències del Mar, Barcelona, Spain, ${ }^{6}$ Red Sea Research Center, King Abdullah University of Science and Technology, Thuwal, Saudi Arabia, ${ }^{7}$ Department of Oceanography, Bermuda Institute of Ocean Sciences, St. Georges, Bermuda, ${ }^{8}$ IIM-CSIC, Instituto de Investigacións Mariñas, Vigo, Spain
\end{abstract}

Marine prokaryotes play a key role in cycling of organic matter and nutrients in the ocean. Using a unique dataset (>14,500 samples), we applied a space-for-time substitution analysis to assess the temperature dependence of prokaryotic heterotrophic production (PHP) in epi- (0-200 m), meso- (201-1000 m) and bathypelagic waters (1001-4000 m) of the global ocean. Here, we show that the temperature dependence of PHP is fundamentally different between these major oceanic depth layers, with an estimated ecosystem-level activation energy $\left(E_{\mathrm{a}}\right)$ of $36 \pm 7 \mathrm{~kJ} \mathrm{~mol}^{-1}$ for the epipelagic, $72 \pm 15$ $\mathrm{kJ} \mathrm{mol}^{-1}$ for the mesopelagic and $274 \pm 65 \mathrm{~kJ} \mathrm{~mol}^{-1}$ for the bathypelagic realm. We suggest that the increasing temperature dependence with depth is related to the parallel vertical gradient in the proportion of recalcitrant organic compounds. These $E_{\mathrm{a}}$ predict an increased PHP of about 5, 12, and 55\% in the epi-, meso-, and bathypelagic ocean, respectively, in response to a water temperature increase by $1^{\circ} \mathrm{C}$. Hence, there is indication that a major thus far underestimated feedback mechanism exists between future bathypelagic ocean warming and heterotrophic prokaryotic activity.

Keywords: prokaryotic production, activation energy, open ocean, global warming, Arrhenius law

\section{INTRODUCTION}

Marine bacteria and archaea, here collectively termed prokaryotes, are central components of marine food webs and play a key role in controlling ocean biogeochemistry. The surface ocean, also known as the epipelagic zone (here considered as the $0-200 \mathrm{~m}$ depth range) receives sufficient light to support photosynthesis, while the dark ocean (below $200 \mathrm{~m}$ depth) is characterized by the absence of light. The dark ocean constitutes the largest habitat of the biosphere, comprising about $95 \%$ of the global ocean volume. This part of the ocean is subdivided into the mesopelagic zone (201-1000 m depth) with water mass renewal times of decades and the bathypelagic (1001$4000 \mathrm{~m}$ depth) and abyssal zones (>4000 $\mathrm{m}$ depth) with water mass renewal times of centuries to millennia (Matsumoto, 2007). Organic matter produced in the ocean is the main substrate for prokaryotic growth and several fractions of this organic matter are recognized to have decreasing 
availability to prokaryotes: a biologically labile fraction which can be processed within hours to days, a semi-labile fraction with turnover times from weeks to months, a semi-recalcitrant fraction that can persist for decades, a recalcitrant fraction with lifetimes of thousands of years, and an ultra- recalcitrant fraction that is resistant to removal for tens of thousands of years (Hansell, 2013). Microbial growth in the dark ocean is mainly supported by the dissolved semi-labile, suspended and sinking particulate organic matter exported from the epipelagic zone and most of this organic matter is degraded in the mesopelagic zone (Arístegui et al., 2009; Herndl and Reinthaler, 2013). Considering that the dark ocean contains around $75 \%$ of all pelagic prokaryotic biomass and a large fraction of the global ocean's removal of organic matter occurs below $200 \mathrm{~m}$ depth (del Giorgio and Duarte, 2002; Arístegui et al., 2009), minor changes in prokaryotic activity due to climate change could have a large impact on ocean functioning, atmospheric $\mathrm{CO}_{2}$ concentrations and the Earth climate system.

Human activities have elevated atmospheric greenhouse gas concentrations leading to increases in global temperatures, with the ocean storing more than $90 \%$ of the extra heat (Collins et al., 2013). Since the beginning of the twentieth century, global average sea surface temperatures has increased by $0.6^{\circ} \mathrm{C}$, with model predictions suggesting a further increase of between 1 and $3^{\circ} \mathrm{C}$ by the end of this century (Collins et al., 2013). Global warming will thereby change biological, chemical and physical processes in the ocean and affect ecosystem functioning and biogeochemical fluxes. As temperature is an important regulator of most biological processes including the metabolic activity of prokaryotes (White et al., 1991; Pomeroy and Wiebe, 2001; López-Urrutia and Morán, 2007; Calvo-Díaz et al., 2014), accurate knowledge on the impact of rising ocean temperatures on biological rates is pivotal for predicting the biosphere's feedback to these changes and how this will impact the global carbon cycle.

In this article, we compiled a unique global dataset of prokaryotic heterotrophic production (PHP) and temperature measurements from all major oceans and depths to assess the temperature dependence of PHP within the ocean. We here hypothesize that, the temperature dependence of PHP might vary between the epipelagic, mesopelagic and bathypelagic zone.

\section{METHODS}

\section{Data Collection}

Data on seawater temperature and prokaryotic heterotrophic production (PHP) were compiled from the literature, mainly from original articles and databases available online, resulting in a total of 14,552 data pairs (Supplementary Table S1). Singledata observations were excluded and no data from manipulated experiments were used. The PHP estimates used in this study are based on two methods: incorporation of ${ }^{3} \mathrm{H}$-thymidine (TdR) and ${ }^{14} \mathrm{C}$ - or ${ }^{3} \mathrm{H}$-leucine (Leu) into bacterial DNA and protein, respectively. In only a few cases (42 data points in total), Leu and $\mathrm{Tdr}$ incorporation obtained in the same sample exhibited a more than 25-fold difference in the PHP estimate. These data points were removed from further analyses and reduced our dataset to a total of 14,510 data pairs. Leucine incorporation was used in $47 \%(n=6819)$ of the data extracted and TdR incorporation was used in 53\% $(n=7691)$. To show the implications of the PHP temperature relationships, we converted the raw data to common carbon units. In order to avoid artifacts due to selection of different carbon conversion factors (CF), all PHP data were converted using a factor of $1.95 \mathrm{~kg} \mathrm{C} \mathrm{mol}^{-1}$ leucine incorporated (Calvo-Díaz and Morán, 2009; Alonso-Sáez et al., 2010), $1.63 \times 10^{18}$ cells mol $^{-1}$ thymidine incorporated (Carlson et al., 1996) and assuming a carbon conversion factor of $12 \mathrm{fg} \mathrm{C}$ cell $^{-1}$ (Fukuda et al., 1998). In the cases where only prokaryotic production estimates were reported we back calculated these to obtain raw values, and thereafter applied our average conversion factors. Multiple CFs have been measured in the past with values ranging widely, 0.13 and $3.62 \mathrm{~kg} \mathrm{C} \mathrm{mol}^{-1}$ leucine, and $0.2-5.60$ $\times 10^{18}$ cells $\mathrm{mol}^{-1}$ thymidine (Carlson et al., 1996; Calvo-Díaz and Morán, 2009; Alonso-Sáez et al., 2010; Baltar et al., 2010), with no clear trends with depth layers of the measured values (e.g., compare the studies of Alonso-Sáez et al., 2007; Baltar et al., 2010 both in the same oceanographic area). A recent study covering the global subtropical and tropical ocean furthermore does not support any clear geographic effect on CFs (Teira et al., 2015), and based on these studies, it cannot be concluded whether deep waters have different CFs than surface waters. The values we use in this study are averages of the most commonly used CFs; had we used lower or higher factors it would not have influenced the slope of the observed relationships between PHP and temperature, but only the origin intercept, i.e., the data position in the plots.

To refine our analysis, we should have used variable conversion factors measured specifically for each ocean region, depth range, and season sampled. But given the lack of empirical CFs reported in the vast majority of the studies included, we can only ignore the potential differences in conversion factors between different oceans and depth ranges as no coherent trends in CFs emerge from the published CFs (Baltar et al., 2010).

Using these conversion factors, a linear relationship was found between Leu and Tdr incorporation in the samples where a dual label approach was used $\left(R^{2}=0.56, n=2848, p<0.0001\right)$, with a slope of $0.97 \pm 0.03$ suggesting that the PHP estimates obtained with either method are not statistically different. Furthermore, we also performed a control analysis of the temperature relationships of the Leu and Tdr estimates separately, showing that our conclusions are not biased by the method used to assess the PHP (Supplementary Figure S1). Although, Leu to TdR ratios provide valuable information in regional studies (e.g., Chin-Leo and Kirchman, 1990; Franco-Vidal and Morán, 2011) for basin-scale to global ranges such as those shown here there is little doubt that both substrates are equally valid for estimating production of heterotrophic prokaryotes.

The data were split according to depth corresponding to the epipelagic (here considered as the depth range from 0 to $200 \mathrm{~m}$ ), mesopelagic (201-1000 $\mathrm{m}$ depth) and the bathypelagic (1001-4000 $\mathrm{m}$ depth) layer and thereafter grouped and averaged within data bins covering $1^{\circ} \mathrm{C}$ (Supplementary Table S2). The data binning step was used to provide an average ocean PHP at a given temperature and the size $\left(1^{\circ} \mathrm{C}\right)$ of these bins was chosen 
to ensure that multiple measurements (average 220) were present in each bin and depth layer. This procedure also forces that all bins have the same weight in the subsequent statistical analyses independently of the number of data that they initially contain. In the abyssal zone $(>4000 \mathrm{~m}$ ) temperature typically varies between 2 and $3^{\circ} \mathrm{C}$. It is therefore not possible to obtain PHP estimates over a wide temperature range, which is a prerequisite to calculate $E_{a}$. Thus, data from these depths were not included in our analyses. We applied a space-for-time approach, which assumes that the measurements over multiple environmental gradients can be used to predict ecological responses to climate change (Blois et al., 2013; Lester et al., 2014).

\section{Arrhenius Law}

The relationship between temperature and biological rates has been modeled in various ways (Ratkowsky et al., 1983; Ahlgren, 1987), while an Arrhenius-type relationship (linearity of a natural logarithm vs. inverse absolute temperature), assuming that chemical kinetics controls the observed rates, is the most widely applied approach (Westrich and Berner, 1988; Middelburg et al., 1996). According to the Arrhenius law, the temperature sensitivity of PHP is defined by:

$$
P H P=A \cdot e^{-E_{a} / R \cdot T}
$$

Where $A$ is the theoretical PHP in the absence of $E_{\mathrm{a}} ; E_{\mathrm{a}}$ is the energy barrier to be surpassed in order for the reaction to take place (in $\mathrm{J} \mathrm{mol}^{-1}$ ); $R$ is the universal gas constant (8.314 $\mathrm{J} \mathrm{mol}^{-1} \mathrm{~K}^{-1}$ ); and $T$ is the temperature in Kelvin $(\mathrm{K})$. The factor $\mathrm{e}^{-E_{a}} / R \cdot T$ is proportional to the fraction of substrate molecules with kinetic energies in excess of $E_{\mathrm{a}}$ (Arrhenius, 1889). An estimate of $E_{\mathrm{a}}$ can be derived from the slope of an Arrhenius plot of $\ln$ PHP against the inverse absolute temperature $(1 / \mathrm{T})$. The $E_{\mathrm{a}}$ can thereafter be calculated by multiplying the regression slope by $R$, the universal gas constant. Strictly, the Arrhenius law should be applied to a well-defined enzymatic reaction with a constant $E_{\mathrm{a}}$ and with temperature as the only factor affecting the rate. Furthermore, as heterotrophic prokaryotes are highly diverse and they degrade organic matter that consists of myriads of compounds, the temperature response measured is in reality the sum of all processes involved and therefore the calculated $E_{\mathrm{a}}$ should be seen as an apparent or ecosystem-level $E_{\mathrm{a}}$ (Westrich and Berner, 1988; Middelburg et al., 1996). Although, this is not the classical definition of $E_{\mathrm{a}}$ (Arrhenius, 1889) it seems appropriate to use the term apparent activation energy to refer to these values.

The temperature sensitivity of biological rates is normally expressed as an increase ratio following a $10^{\circ} \mathrm{C}$ increase $\left(Q_{10}\right)$ in temperature. As the ocean will most likely experience temperature increases of a few $\left(1-4^{\circ} \mathrm{C}\right)$ degrees Celsius over the next decades, we calculated the increase in PHP compared to a water temperature increase of $1^{\circ} \mathrm{C}\left(Q_{1}\right)$ instead of $10^{\circ} \mathrm{C}$ using the following formula:

$$
Q_{1}=e^{\frac{E_{a}}{R} \frac{1}{T_{1} T_{2}}}
$$

Linear regression analyses were used for the Arrhenius plots. Prior to regressions, normality was checked and the confidence level was set at $95 \%$, with all statistical analyses conducted in $\mathrm{R}$ version 3.1.0 (Development core team $\mathrm{R}, 2014$ ).

\section{RESULTS}

We have compiled and harmonized a total of 14,510 pairs of concurrent measurements of open ocean water temperature and prokaryotic heterotrophic production rates to test, using a spacefor-time substitution analysis, the in situ response of prokaryote activity to temperature in epi-, meso-, and bathypelagic waters of the world ocean. The individual depth layers contained data from each major ocean. In the epipelagic layer most (51\%) data points were collected in the Atlantic Ocean, followed by the Pacific Ocean (15\%) and Arabian Sea (13\%). In the mesopelagic layer the Atlantic Ocean contributed again with the largest fraction (51\%), followed by the Arabian Sea (12\%), Cariaco Basin (14\%), Pacific Ocean (12\%), and Ross Sea (10\%), which contributed almost equally. In the bathypelagic layer the data points were dominated by measurements from the Atlantic Ocean (40\%), Arabian Sea (30\%), and Pacific Ocean (26\%). Most of the data pairs corresponded to the epipelagic (77\%), followed by the mesopelagic (15\%) and bathypelagic (8\%) layers (Table 1). In this study we aggregate data from regions that have different environmental conditions, which could potentially bias our dataset. To test if the PHP varied systematically between areas, we plotted all PHP and temperature data in the epi-, meso-, and bathypelagic layers from each region using box-andwhiskers plots (Supplementary Figure S2). These plots show that the variability in the PHP is large, but that no systematic bias is apparent between regions or studies (Supplementary Figure S2).

The average seawater temperature was $17.8 \pm 8.8^{\circ} \mathrm{C}$ (range: $\left.-1.9-31.1^{\circ} \mathrm{C}\right), 11.5 \pm 6.3^{\circ} \mathrm{C}\left(-2.0-19.0^{\circ} \mathrm{C}\right)$, and $3.1 \pm$ $1.8^{\circ} \mathrm{C}\left(-0.4\right.$ and $\left.9.1^{\circ} \mathrm{C}\right)$ in the epi-, meso-, and bathypelagic waters, respectively (Table 1). Globally, the average PHP in the epipelagic $\left(61 \pm 110 \mu \mathrm{mol} \mathrm{C} \mathrm{m}{ }^{-3} \mathrm{~d}^{-1}\right)$ was about 10 times larger than in the mesopelagic $\left(6 \pm 15 \mu \mathrm{mol} \mathrm{C} \mathrm{m}{ }^{-3} \mathrm{~d}^{-1}\right)$, which in turn was around 1.7 times higher than in the bathypelagic layer $(4 \pm$ $\left.11 \mu \mathrm{mol} \mathrm{C} \mathrm{m}{ }^{-3} \mathrm{~d}^{-1}\right)$. This approximate 10 -fold average decrease in the PHP from the epipelagic to the bathypelagic layer (Table 1, Figure 1), follows closely the decrease in temperature, average temperature difference between the epi- and bathypelagic ocean is about $15^{\circ} \mathrm{C}$ (Table 1), and the decreasing organic matter supply and bioavailability (Herndl and Reinthaler, 2013; Reinthaler et al., 2013).

After grouping the data of each depth layer by temperature bins of $1^{\circ} \mathrm{C}$, we analyzed the temperature dependence of PHP using Arrhenius plots and observed significantly different linear regressions between $\ln \mathrm{PHP}$ and $1 / \mathrm{T}(p<0.001)$ for the three layers (Figure 2). The apparent activation energies $\left(E_{\mathrm{a}}\right)$ derived from the regression slopes of the Arrhenius plots were $36 \pm 7 \mathrm{~kJ}$ $\mathrm{mol}^{-1}$ in the epipelagic, about half in the mesopelagic layer (72 $\pm 15 \mathrm{~kJ} \mathrm{~mol}^{-1}$ ), which in turn was about 4.5 times lower than for the bathypelagic layer $\left(274 \pm 65 \mathrm{~kJ} \mathrm{~mol}^{-1}\right)$. These numbers were significantly different among them: T-Student was $2.167(p<0.1)$ 
TABLE 1 | Summary of data used with the temperature and prokaryotic heterotrophic production (PHP) ranges and averages ( \pm standard deviations) reported for the epipelagic (0-200 m), mesopelagic (201-1000 m) and bathypelagic (1001-4000 m) zones of the global ocean.

\begin{tabular}{|c|c|c|c|c|c|c|c|}
\hline Layer & $\begin{array}{c}\text { Temp. Range } \\
\left({ }^{\circ} \mathrm{C}\right)\end{array}$ & $\begin{array}{c}\text { Temp. Avg } \\
\left({ }^{\circ} \mathrm{C}\right)\end{array}$ & 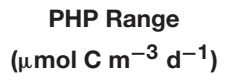 & $\begin{array}{c}\text { PHP Avg. } \\
\left(\mu \mathrm{mol} \mathrm{C} \mathrm{m}^{-3} \mathrm{~d}^{-1}\right)\end{array}$ & $\begin{array}{c}E_{a} \\
\left(\mathrm{~kJ} \mathrm{~mol}^{-l}\right)\end{array}$ & $Q_{1}$ & $N$ \\
\hline Epipelagic & {$[-1.9,31.1]$} & $17.8 \pm 8.8$ & {$[0.02,4042]$} & $61 \pm 110$ & $36 \pm 7$ & $5 \pm 1 \%$ & 11,186 \\
\hline Mesopelagic & {$[-2.0,19.0]$} & $11.5 \pm 6.3$ & {$[0.008,315.1]$} & $6 \pm 15$ & $72 \pm 15$ & $12 \pm 3 \%$ & 2228 \\
\hline Bathypelagic & {$[-0.4,9.1]$} & $3.1 \pm 1.8$ & {$[0.004,138.3]$} & $4 \pm 11$ & $274 \pm 65$ & $55 \pm 16 \%$ & 1096 \\
\hline
\end{tabular}

The apparent or ecosystem level activation energy, $E_{a}$ obtained applying the Arrhenius law to PHP rates from each layer is also reported. $Q_{1}$ represents the relative increase of PHP in response to a $1^{\circ} \mathrm{C}$ increase around the average temperature (Temp. Avg) of each layer and $\mathrm{N}$ is the number of data points in each depth layer.

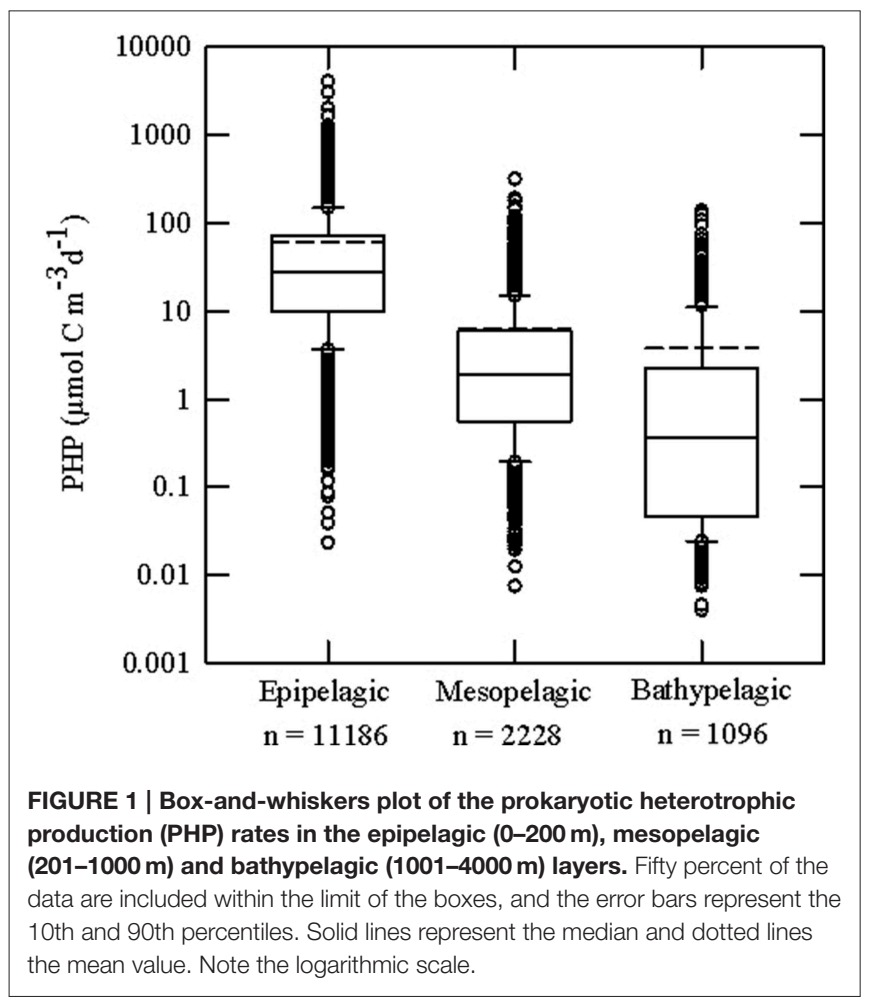

when comparing the epi- and mesopelagic layers and $3.003(p<$ 0.01 ) when comparing the meso- and bathypelagic layers. These $E_{\mathrm{a}}$ translate into relative increases of $\mathrm{PHP}$ in response to a $1^{\circ} \mathrm{C}$ increase of $5 \%$ for the epipelagic, $12 \%$ for the mesopelagic and $55 \%$ for the bathypelagic zone (Table $\mathbf{1}$ ).

\section{DISCUSSION}

\section{Application of Ecosystem Level Activation Energies in Earth Sciences}

The Arrhenius law has previously been used in marine sciences for calculating the apparent $E_{\mathrm{a}}$ of the ocean's metabolic balance and explaining its temperature dependence under its recent reformulation within the metabolic theory of ecology (MTE) (Brown et al., 2004; López-Urrutia et al., 2006). The MTE scales the metabolic rates by combining the effects of body size and temperature, suggesting that autotrophic and heterotrophic processes in marine systems will react differently to ocean warming, thus possibly changing the metabolic balance leading to a more heterotrophic ocean (Yvon-Durocher et al., 2012). In soils the temperature sensitivity of microbial organic matter degradation has been studied extensively (Davidson et al., 2000; Davidson and Janssens, 2006), demonstrating that increasing ambient temperature preferentially stimulates the microbial degradation of the more recalcitrant organic matter fractions. These results led to the formulation of the carbon quality temperature (CQT) hypothesis (Davidson et al., 2000; Davidson and Janssens, 2006; Kleber, 2010), which is based on the principles of enzyme kinetics combined with the Arrhenius law. According to the CQT hypothesis, substrate quality can be defined by changes in $E_{\mathrm{a}}$, which is the energy barrier to be surpassed for substrate degradation to take place. Thus, the more recalcitrant the substrate, the higher its $E_{\mathrm{a}}$ and, following the Arrhenius law, the higher its temperature sensitivity to microbial degradation (Bosatta and Ågren, 1999; Sierra, 2011).

The CQT hypothesis has not been tested yet in the dark ocean, where most of the organic matter consists of recalcitrant compounds (Hansell, 2013). The $E_{\mathrm{a}}$ of the epipelagic and mesopelagic zones found in this study were similar to values found for organic matter degradation in marine sediments and soils (Middelburg et al., 1996; Craine et al., 2010), while the bathypelagic was similar to an $E_{\mathrm{a}}$ recently proposed $(\sim 200 \mathrm{~kJ}$ $\mathrm{mol}^{-1}$ ) for the degradation of recalcitrant organic matter in marine sediments (Burdige, 2011). The increase of apparent $E_{\mathrm{a}}$ with depth that we report here (Table 1) agrees with the predictions of the CQT hypothesis, suggesting that marine microbes degrading more recalcitrant compounds with higher $E_{\mathrm{a}}$ have higher temperature sensitivity (Bosatta and Ågren, 1999; Sierra, 2011). Although it should be kept in mind that PHP in the deep ocean is not only fuelled by recalcitrant compounds since sinking particles and physical transport can export labile compounds to the ocean interior (Carlson et al., 2010; Follett et al., 2014). Furthermore, the $E_{\mathrm{a}}$ for the epipelagic layer was somewhat below the $E_{\mathrm{a}}$ value of $62.7 \mathrm{~kJ} \mathrm{~mol}^{-1}$ that has been predicted by recent theories for overall heterotrophic organism metabolism, suggesting that factors other than temperature (e.g., substrate) also limit the PHP in this layer (Brown et al., 2004; López-Urrutia and Morán, 2007). In the mesopelagic zone the $E_{\mathrm{a}}$ of $72 \pm 15 \mathrm{~kJ} \mathrm{~mol}^{-1}$ was very close to the theoretical value, suggesting that temperature is one of the main limiting factors for the PHP in this layer. However, the $E_{\mathrm{a}}$ for the bathypelagic 


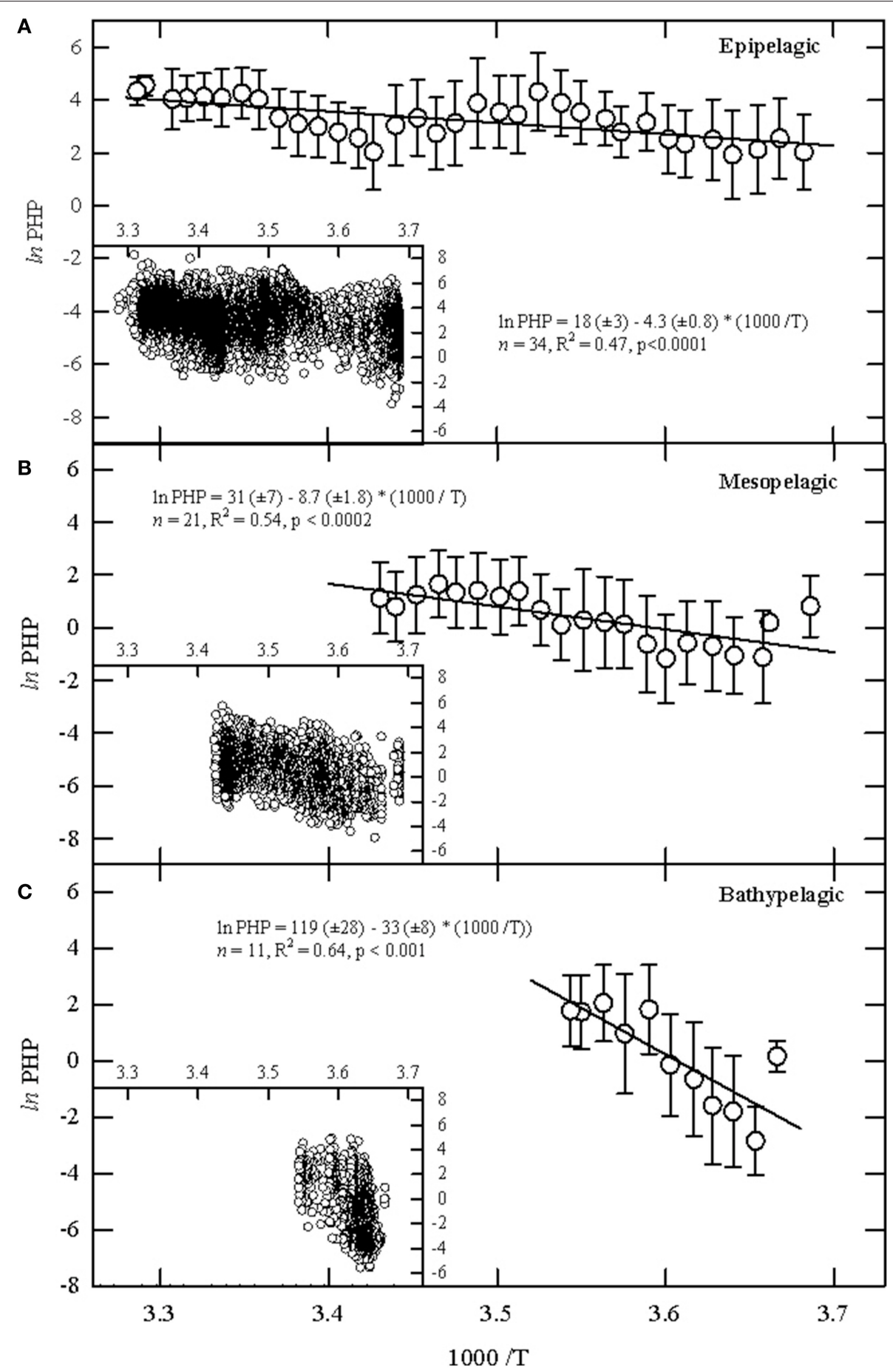

FIGURE 2 | Arrhenius plots of the natural logarithm of the prokaryotic heterotrophic production (In PHP) against the inverse absolute temperature $(1 / T)$ for the (A) epipelagic (0-200 m), (B) mesopelagic (201-1000 m), and (C) bathypelagic (1001-4000 m) sets of samples. The error reported for the PHP grouped samples by $1^{\circ} \mathrm{C}$ bins represent the standard deviation. Solid lines represent the corresponding regression lines with the origin intercept and slope of the regression equations and their corresponding standard errors; $R^{2}$, coefficient of determination. The inset in each graph shows the raw data for each depth layer.

is approximately 3 times larger than the theoretical value, which might reflect fundamental differences in either prokaryotic physiology, organic matter supply, organic matter composition or a combination of these, compared to the shallower depth layers (Brown et al., 2004; López-Urrutia et al., 2006; López-Urrutia and Morán, 2007; Yvon-Durocher et al., 2012). 


\section{Other Factors Affecting the Prokaryote Production to Temperature Relationship}

The varying relationship between PHP and temperature between depth layers could also be constrained by factors such as varying cell abundance and size, inorganic nutrient concentrations, dissolved oxygen, UV-light exposure, taxonomy/genomic potential, decompression effects, and the amount, bioavailability or extreme dilution of individual organic substrates (Benner, 2002; Mopper and Kieber, 2002; Kattner et al., 2011). Prokaryotic cell abundances were reported in a subset of the dataset included in our analysis $(n=7597)$. Cell-specific PHP rates and the corresponding $E_{\mathrm{a}}$, ranging between $38 \pm 8 \mathrm{~kJ} \mathrm{~mol}^{-1}$ (epipelagic) and $228 \pm 45 \mathrm{~kJ} \mathrm{~mol}^{-1}$ (bathypelagic layer) (Supplementary Figure S3), showed a similar pattern compared to the whole dataset and the bulk PHP rates $(n=14,510)$. This suggests that varying cell abundances were not a major factor for the differences in $E_{\mathrm{a}}$ among depth layers. The MTE predicts that cell size should decrease with increasing temperatures thereby affecting the organism metabolism and resulting in a higher $E_{\mathrm{a}}$, as shown for phytoplankton communities (Gillooly et al., 2001). For heterotrophic prokaryotes most studies have focused on the impact of temperature on metabolic rates. Generally, these studies indicate an increase in specific growth rate, PHP, and respiration with elevated temperatures (White et al., 1991; López-Urrutia and Morán, 2007; Vázquez-Dominguez et al., 2007), and even suggest that heterotrophic prokaryotes might have the ability to adjust their body size (Morán et al., 2015). We unfortunately do not have data on cell size distribution in the different depth layers and, therefore, cannot judge how this might impact the observed temperature-PHP relationships. PHP has also been shown to depend on the concentrations of inorganic nutrients (Gasol et al., 2009), likely influencing our PHP rates in the epipelagic, but not in the meso- and bathypelagic zones, where inorganic nutrient levels are well above limiting concentrations. Low dissolved oxygen concentration has been shown to impact the metabolic pathways and taxonomic composition of prokaryotic communities, and anaerobic degradation of organic matter is generally assumed to be slower than aerobic degradation (Lee, 1992; Quiñones et al., 2009). The dataset presented here includes sites with occasionally very low oxygen concentrations in mesopelagic zones such as in the Arabian Sea and the Cariaco Basin. As the PHP rates and temperatures found in these areas were similar to values found in other ocean regions, we considered the influence of low oxygen on our apparent $E_{\mathrm{a}}$ values negligible. UV-radiation is known to influence PHP both directly and indirectly through e.g., photochemical induced transformation of organic matter (Herndl et al., 1993; Mopper and Kieber, 2002; Ruiz-González et al., 2013). Most of the measurements included in this study were conducted in the dark, thus it is not possible to assess how direct or previous sunlight exposure in the photic zone might have influenced the rates measured. The ocean's prokaryotic community composition has been shown to vary both with depth and over spatial and temporal scales, with potential impacts on the PHP rates (DeLong et al., 2006; Sunagawa et al., 2015). We do not have prokaryote diversity estimates available for our dataset and we can therefore not judge how changes in the community composition might impact our apparent $E_{\mathrm{a}}$ values. Future studies, combining PHP measurements with diversity estimates over large temperature and depth ranges will be needed to address these relationships. All our mesopelagic and bathypelagic samples were decompressed prior to measuring PHP. Whether, decompression of deep sea samples lead to an increased or decreased prokaryotic activity is still a major unknown (Tamburini et al., 2013). In order to estimate the effect of decompression on the $E_{\mathrm{a}}$ we subdivided our mesopelagic and bathypelagic data into two depth intervals and found that the apparent $E_{\mathrm{a}}$ values were constant between these depth layers (Supplementary Figure S4). This suggests that while the overall PHP rates might have been different under in situ and decompressed conditions, the obtained temperature relationships are independent of the pressure effect. Our estimated $E_{\mathrm{a}}$ might also be influenced by the amount, bioavailability or extreme dilution of individual organic substrates. Recently, it has been argued that the dark ocean organic matter pool contains hundreds of thousands of individual compounds at extremely dilute concentrations (Kattner et al., 2011; Arrieta et al., 2015). Thus, molecular diffusion of individual compounds could be the limiting factor for prokaryotic growth. It is well known that increasing temperature impacts the molecular diffusion of organic molecules, however, the $E_{\mathrm{a}}$ for diffusion about $15 \mathrm{~kJ} \mathrm{~mol}^{-1}$ (Oelkers, 1991), is too low to explain the extremely high ecosystem-level $E_{\mathrm{a}}$ in the bathypelagic realm. Alternatively, it could be argued that prokaryotic cells may switch to a maintenance mode by down-regulating their enzymatic activity when the diffusive substrate encounter rate is energetically unfavorable (Egli, 1995). This suppression of enzymatic activity would lead to an increased $E_{\mathrm{a}}$. Previous works have also suggested that planktonic communities growing at lower temperatures will have a steeper response to increased temperature, which has been linked to a covariation between temperature and substrate availability (see review by (Pomeroy and Wiebe, 2001) for further information and references). For the epipelagic samples an argument could be made that there are two different temperature gradients (Figure 2A), so that microbes living in warm and cold environments would response differently to increasing temperatures. Whether similar covariations between temperature and substrate exist for our mesopelagic and bathypelagic samples is not clear from the available data and further studies are therefore needed to elucidate such relationships.

\section{Implication for an Ocean under Global Warming}

Our analysis of the temperature dependence of PHP using an Arrhenius type relationship has shown that the resultant apparent activation energies $\left(E_{\mathrm{a}}\right)$ are fundamentally different between the epi-, meso-, and bathypelagic ocean layers (Table 1). Since the $E_{\mathrm{a}}$ is particularly high in the bathypelagic layer compared with the epi- and mesopelagic layers, it suggests that dark ocean microbes are the most sensitive to global warming. 
Over the last years it has become evident that the rate of upperocean-warming has leveled off, showing only a modest warming over the last decade (Meehl et al., 2011; Balmaseda et al., 2013). This has been mainly explained by the gradual heat absorption of the dark ocean, with approximately $30 \%$ of the ocean warming occurring below $1000 \mathrm{~m}$ depth and an average increase of $0.003^{\circ} \mathrm{C}$ year $^{-1}$ (Meehl et al., 2011; Balmaseda et al., 2013). Accordingly, this temperature increase would stimulate the dark ocean PHP more than the PHP of their epi- and mesopelagic counterparts. The apparent $E_{\mathrm{a}}$ we obtained would predict an increased PHP by about 5,12 , and $55 \%$ in the epi-, meso- and bathypelagic ocean in response to an increase in water temperature of $\sim 1^{\circ} \mathrm{C}$. Thus, global warming could cause a non-steady state condition to which the microbes may acclimatize, reaching a new equilibrium over time. Whether increasing temperatures have long-lasting and major impacts on the prokaryotic community, indicating a progressive acclimation of the prokaryotic community, or whether they quickly adapt to the elevated temperatures, remains to be seen. Long term (years) heating experiments in soils have shown that microbial activity returns to pre-warming values within a few years, likely due to a depletion of labile organic matter pools and/or thermal adaptation of the microbial community to the increased temperatures (e.g., Bradford et al., 2008; Rousk et al., 2012). Microbial temperature adaptation has also been demonstrated in lakes (Hall and Cotner, 2007; Hall et al., 2008) and similar mechanisms could also be at play in the ocean, but experimental data to support this are still missing.

Considering that heterotrophic prokaryotes play key roles in the oceanic carbon cycle, minor changes in their productivity due to increased temperature could have major impacts on the ocean carbon fluxes. It must be noted that our analysis uses only biomass production by heterotrophic prokaryotes, not the total consumption of organic matter (PHP plus respiration (PHR)). Hence a differential growth efficiency (PHP/(PHP+PHR)) with depth, related to changes in temperature (Rivkin and Legendre, 2001) or in the quality and availability of the organic matter consumed (LópezUrrutia and Morán, 2007; Vázquez-Dominguez et al., 2007; Alonso-Sáez et al., 2008) could also play an important role in determining the impacts of the observed responses. As prokaryotic respiration measurements are scarce, especially in the deep ocean, future studies to resolve the interactions between prokaryotes carbon cycling and climate change could benefit from combining the field estimates with global biogeochemical models (e.g., Bendtsen et al., 2002; Hasumi and Nagata, 2014).

\section{REFERENCES}

Ahlgren, G. (1987). Temperature functions in biology and their application to algal growth constants. Oikos 49, 177-190. doi: 10.2307/3566025

Alonso-Sáez, L., Gasol, J. M., Arístegui, J., Vilas, J. C., Vaqué, D., Duarte, C. M., et al. (2007). Large-scale variability in surface bacterial carbon demand and growth efficiency in the subtropical northeast Atlantic Ocean. Limnol. Oceanogr. 52, 533-546, doi: 10.4319/lo.2007.52.2.0533

\section{CONCLUSIONS}

We suggest that (1) the assumption that prokaryotes in the ocean will uniformly react to increasing temperature is not valid along the depth gradient; and (2) the empirically estimated $E_{\mathrm{a}}$ values indicate that increasing ocean temperature will enhance prokaryotic production in the deep realm of the ocean more than in surface waters. This differential behavior of the dark ocean might have far reaching consequences for the overall carbon balance of the global ocean.

\section{AUTHOR CONTRIBUTIONS}

CL, LC contributed equally to the data survey. TR, GH, XM, and JG provided raw data. CL, XA analyzed the data, devised the research and wrote the first draft of the manuscript. LC, TR, GH, JG, XM, and NB commented and discussed on the manuscript.

\section{ACKNOWLEDGMENTS}

Financial support for this project was provided by the Australian Institute of Marine Science (AIMS) and a grant from the Carlsberg Foundation to CL. XA, XM and JG were funded by the Malaspina expedition 2010 (grant $\mathrm{n}^{\circ}$ CSD2008-00077) and HOTMIX (grant $\mathrm{n}^{\circ}$ CTM2011-30010-C02-02) projects. TR was supported by the PADOM project (Austrian Science Fund grant $\mathrm{n}^{\circ}$ P23221-B11). GH was funded by the Austrian Science Fund (FWF) project I486-B09 and by the European Research Council under the European Community's Seventh Framework Programme (FP7/2007-2013)/ERC grant agreement No. 268595 (MEDEA project). We thank A. Gomes and the scientists and technicians on board Malaspina for their help. The British Oceanographic Data Centre (BODC) is acknowledged for supplying data for this analysis. We also acknowledge the large efforts made by Hugh Ducklow and David L. Kirchman and their teams in generating the data of the US JGFOS program. The data providers at the Bermuda Atlantic Time-Series Study (BATS) and Cariaco Basin Time-Series (CARIACO) are also acknowledged. A part of the Mediterranean data was obtained through the Biosope project funded through CNRS-INSU grants. Murray Logan is thanked for his input on using linear regression in $\mathrm{R}$.

\section{SUPPLEMENTARY MATERIAL}

The Supplementary Material for this article can be found online at: http://journal.frontiersin.org/article/10.3389/fmars. 2016.00090 
marine system. Ecosystems 11, 397-409. doi: 10.1007/s10021-0089129-0

Arístegui, J., Gasol, J. M., Duarte, C. M., and Herndl, G. J. (2009). Microbial oceanography of the dark ocean's pelagic realm. Limnol. Ocean. 54, 1501-1529. doi: 10.4319/lo.2009.54.5.1501

Arrhenius, S. Z. (1889). Über die reaktionsgeschwindigkeit bei der inversion von rohrzucker durch säuren. Phys. Chem. 4, 226-248.

Arrieta, J. M., Mayol, E., Hansman, R. L., Herndl, G. J., Dittmar, T., and Duarte, C. M. (2015). Dilution limits dissolved organic carbon utilization in the deep ocean. Science 348, 331-333. doi: 10.1126/science.1258955

Balmaseda, M. A., Trenberth, K. E., and Källén, E. (2013). Distinctive climate signals in reanalysis of global ocean heat content. Geo. Phys. Res. Let. 40, 1754-1759. doi: 10.1002/grl.50382

Baltar, F., Arístegui, J., Gasol, J. M., and Herndl, G. J. (2010). Prokaryotic carbon utilization in the dark ocean: growth efficiency, leucine-to-carbon conversion factors, and their relation. Aquat. Microb. Ecol. 60, 227-232. doi: 10.3354/ame01422

Bendtsen, J., Lundsgaard, C., Middelboe, M., and Archer, D. (2002). Influence of bacterial uptake on deep-ocean dissolved organic carbon. global biogeochem. cycles 16, 1127. doi: 10.1029/2002GB001947

Benner, R. (2002). "Chemical composition and reactivity", in Biogeochemistry of Marine Dissolved Organic Matter, eds D. A. Hansell, and C. A. Carlson (San Diego, CA: Academic press), 59-90.

Blois, J. L., Williams, J. W., Fitzpatrick, M. C., Jackson, S. T., and Ferrier, S. (2013). Space can substitute for time in predicting climate-change effects on biodiversity. Proc. Nat. Acad. Sci. 110, 9374-9379. doi: $10.1073 /$ pnas. 1220228110

Bosatta, E., and Ågren, G. I. (1999). Soil organic matter quality interpreted thermodynamically. Soil Biol. Biochem. 31, 1889-1891. doi: 10.1016/S00380717(99)00105-4

Bradford, M. A., Davies, C. A., Frey, S. D., Maddox, T. R., Melillo, J. M., Mohan, J. E., et al. (2008). Thermal adaptation of soil microbial respiration to elevated temperature. Ecol. Lett. 11, 1316-1327. doi: 10.1111/j.1461-0248.2008. 01251.x

Brown, J. H., Gillooly, J. F., Allen, A. P., Savage, V. M., and West, G. B. (2004). Toward a metabolic theory of ecology. Ecology 85, 1771-1789. doi: 10.1890/039000

Burdige, D. J. (2011). Temperature dependence of organic matter remineralization in deeply buried marine sediments. Earth Plant. Sci. Lett. 311, 396-410. doi: 10.1016/j.epsl.2011.09.043

Calvo-Díaz, A., Franco-Vidal, L., and Morán, X. A. G. (2014). Annual cycles of bacterioplankton biomass and production suggest a general switch between temperature and resource control in temperate coastal ecosystems. J. Plank. Res. 36, 859-865. doi: 10.1093/plankt/fbu022

Calvo-Díaz, A., and Morán, X. A. G. (2009). Empirical leucine-to-carbon conversion factors for estimating bacterial heterotrophic production, seasonality and predictability in a temperate coastal ecosystem. Appl. Environ. Micro. 75, 3216-3221. doi: 10.1128/AEM.01570-08

Carlson, C. A., Ducklow, H. W., and Sleeter, T. D. (1996). Stocks and dynamics of bacterioplankton in the Northwestern Sargasso Sea. Deep-Sea Res. Part II 43, 491-515. doi: 10.1016/0967-0645(95)00101-8

Carlson, C. A., Hansell, D. A., Nelson, N. B., Siegel, D. A., Smethie, W. M., Khatiwala, S., et al. (2010). Dissolved organic carbon export and subsequent remineralization in the mesopelagic and bathypelagic realms of the North Atlantic basin. Deep Sea Res. Part II 57, 1433-1445. doi: 10.1016/j.dsr2.2010.02.013

Chin-Leo, G., and Kirchman, D. L. (1990). Unbalanced growth in natural assemblages of marine bacterioplankton. Mar. Ecol. Prog. Ser. 63, 1-8.

Collins, M., Knutti, R., Arblaster, J., Dufresne, J.-L., Fichefet, T., Friedlingstein, P., et al. (2013). "Long-term climate change, projections, commitments and irreversibility" in Climate Change 2013, The Physical Science Basis. Contribution of Working Group I to the Fifth Assessment Report of the Intergovernmental Panel on Climate Change, eds T. F. Stocker, D. Qin, G.-K. Plattner, M. Tignor, S. K. Allen, J. Boschung, A. Nauels, Y. Xia, V. Bex, and P. M. Midgley (New York, NY: Cambridge University Press), 1029-1136

Craine, J. M., Fierer, N., and McLauchlan, K. K. (2010). Widespread coupling between the rate and temperature sensitivity of organic matter decay. Nat. Geosci. 3, 854-857. doi: 10.1038/ngeo1009
Davidson, E. A., and Janssens, I. (2006). Temperature sensitivity of soil carbon decomposition and feedbacks to climate change. Nature 440, 165-173. doi: 10.1038 /nature 04514

Davidson, E. A., Trumbore, S. E., and Amundson, R. (2000). Soil warming and organic carbon content. Nature 408, 789-790. doi: 10.1038/35 048672

del Giorgio, P. A., and Duarte, C. M. (2002). Respiration in the open ocean. Nature 420, 379-384. doi: 10.1038/nature01165

DeLong, E. F., Preston, C. M., Mincer, T., Rich, V., Hallam, S. J., Frigaard, N. U., et al. (2006). Community genomics among stratified microbial assemblages in the ocean's interior. Science 311, 496-503. doi: 10.1126/science.1120250

Development core team R. (2014). A Language and Environment for Statistical Computing. Vienna: R Foundation for Statistical Computing. Available online at: http//www.R-project.org/

Egli, T. (1995). The ecological and physiological significance of the growth of heterotrophic microorganisms with mixtures of substrates. Adv. Microb. Ecol. 14, 305-386. doi: 10.1007/978-1-4684-7724-5_8

Follett, C. L., Repeta, D. J., Rothman, D. H., Xu, L., and Santinelli, C. (2014). Hidden cycle of dissolved organic carbon in the deep ocean. Proc. Nat. Acad. Sci. U.S.A. 111, 16706-16711. doi: 10.1073/pnas.1407445111

Franco-Vidal, L., and Morán, X. A. G. (2011). Relationships between coastal bacterioplankton growth rates and biomass production: comparison of leucine and thymidine uptake with single-cell physiological characteristics. Microb. Ecol. 61, 328-341. doi: 10.1007/s00248-010-9778-3

Fukuda, R., Ogawa, H., Nagata, T., and Koike, I. (1998). Direct determination of carbon and nitrogen contents of natural bacterial assemblages in marine environments. Appl. Environ. Micro. 64, 3352-3358.

Gasol, J. M., Vázquez-Domínguez, E., Vaqué, D., Agustí, S., and Duarte, C. M. (2009). Bacterial activity and diffusive nutrient supply in the oligotrophic Atlantic Ocean. Aquat. Microb. Ecol. 56, 1-12. doi: 10.3354/ame 01310

Gillooly, J. F., Brown, J. H., West, G. B., Savage, V. M., and Charnov, E. L. (2001) Effects of size and temperature on metabolic rate. Science 293, 2248-2251. doi: $10.1126 /$ science. 1061967

Hall, E. K., and Cotner, J. B. (2007). Interactive effect of temperature and resources on carbon cycling by freshwater bacterioplankton communities. Aquat. Microb. Ecol. 49, 35-45 doi: 10.3354/ame01124

Hall, E. K., Neuhauser, C., and Cotner, J. B. (2008). Towards a mechanistic understanding of how natural bacterial communities respond to changes in temperature in aquatic ecosystems. ISME J. 2, 471-481. doi: 10.1038/ismej.2008.9

Hansell, D. A. (2013). Recalcitrant dissolved organic carbon fractions. Annu. Rev. Mar. Sci. 5, 421-445. doi: 10.1146/annurev-marine-120710-100757

Hasumi, H., and Nagata, T. (2014). Modeling the global cycle of marine dissolved organic matter and its influence on marine productivity. Ecol. Model. 288, 9-24. doi: 10.1016/j.ecolmodel.2014.05.009

Herndl, G. J., Muller-Niklas, G., and Frick, J. (1993). Major role of ultraviolet-B in controlling bacterioplankton growth in the surface-layer of the ocean. Nature 361, 717-719. doi: 10.1038/361717a0

Herndl, G. J., and Reinthaler, T. (2013). Microbial control of the dark end of the biological pump. Nat. Geosci. 6, 718 -724. doi: 10.1038/ngeo1921

Kattner, G., Simon, M., and Koch, B. (2011). "Molecular characterization of dissolved organic matter and constraints for prokaryotic utilisation," in Microbial Carbon Pump in the Ocean, eds N. Jiao, F. Azam, S. Sanders (Washington, DC: American Association for the Advance in Science), 60-61.

Kleber, M. (2010). What is recalcitrant soil organic matter? Environ. Chem. 7, 320-332. doi: 10.1071/EN10006

Lee, C. (1992). Controls on organic carbon preservation, the use of stratified water bodies to compare intrinsic rates of decomposition in oxic and anoxic systems. Geochim. Cosmochim. Acta 56, 3323-3335. doi: 10.1016/0016-7037(92) 90308-6

Lester, R. E., Close, P. G., Barton, J. L., Pope, A. J., and Brown, S. C. (2014). Predicting the likely response of data-poor ecosystems to climate change using space-for-time substitution across domains. Glob. Change Biol. 20, 3471-3481. doi: $10.1111 /$ gcb.12634

López-Urrutia, Á., and Morán, X. A. G. (2007). Resource limitation of bacterial production distorts the temperature dependence of oceanic carbon cycling. Ecology 88, 817-822. doi: 10.1890/06-1641 
López-Urrutia, A., San Martin, E., Harris, R. P., and Irigoien, X. (2006). Scaling the metabolic balance of the oceans. Proc. Nat. Acad. Sci. U.S.A. 103, 8739-8744. doi: $10.1073 /$ pnas.0601137103

Matsumoto, K. (2007). Radiocarbon-based circulation age of the world oceans. J. Geophys. Res. Ocean. 112, 2156-2202. doi: 10.1029/2007jc004095

Meehl, G. A., Arblaster, J., Fasullo, J., Hu, A., and Trenberth, K. (2011). Model based evidence of deep ocean heat uptake during surface temperature hiatus periods. Nat. Clim. Chan. 1, 360-364. doi: 10.1038/nclimate1229

Middelburg, J. J., Klaver, G., Nieuwenhuize, J., Wielemaker, A., de Haas, W., and van der Nat, J. F. W. A. (1996). Organic matter mineralization in intertidal sediments along an estuarine gradient. Mar. Ecol. Prog. Ser. 132, 157-168. doi: $10.3354 /$ meps 132157

Mopper, K., and Kieber, D. J. (2002). "Photochemistry and the cycling of carbon, sulfur, nitrogen and phosphorus," in Biogeochemistry of Marine Dissolved Organic Matter, eds D. A. Hansell, and C. A. Carlson (San Diego, CA: Academic press), 455-508

Morán, X. A. G., Alonso-Sáez, L., Nogueira, E., Ducklow, H. W., González, N., López-Urrutia, Á., et al. (2015). More, smaller bacteria in response to ocean's warming? Proc. Royal Soc. B Biol. Sci. 282:20150371. doi: $10.1098 /$ rspb. 2015.0371

Oelkers, E. H. (1991). Calculation of diffusion coefficients for aqueous organic species at temperatures from 0 to $350^{\circ}$ C. Geochim. Cosmochim. Acta 55, 3515-3529. doi: 10.1016/0016-7037(91)90052-7

Pomeroy, L. R., and Wiebe, W. J. (2001). Temperature and substrates as interactive limiting factors for marine heterotrophic bacteria. Aquat. Microb. Ecol. 23, 187-204. doi: 10.3354/ame023187

Quiñones, R. A., Levipan, H. A., and Urrutia, H., (2009). Spatial and temporal variability of planktonic archaeal abundance in the Humboldt current system off Chile. Deep Sea Res. Part II, 56, 1073-1082. doi: 10.1016/j.dsr2.2008.09.012

Ratkowsky, D. A., Lowry, R. K., McMeekin, T. A., Stokes, A. N., and Chandler, R. E. (1983). Model for bacterial culture growth rate throughout the entire biokinetic temperature range. J. Bacteriol. 154, 1222-1226.

Reinthaler, T., Álvarez-Salgado, X. A., Álvarez, M., and van Aken, H. M., Herndl, G. J. (2013). Impact of water mass mixing on the biogeochemistry and microbiology of the Northeast Atlantic deep water. Glob. Biogeochem. Cycles 27, 1151-1162. doi: 10.1002/2013GB004634

Rivkin, R. B., and Legendre, L. (2001). Biogenic carbon cycling in the upper ocean, effects of microbial respiration. Science 291, 2398-2400. doi: $10.1126 /$ science.291.5512.2398

Rousk, J., Frey, S. D., and Baath, E. (2012). Temperature adaptation of bacterial communities in experimentally warmed forest soils. Glob. Change Biol. 18, 3252-3258. doi: 10.1111/j.1365-2486.2012.02764.x

Ruiz-González, C., Simó, R., Sommaruga, R., and Gasol, J. M. (2013). Away from darkness: a review on the effects of solar radiation on heterotrophic bacterioplankton activity. Front. Microbiol. 4:131. doi: 10.3389/fmicb.2013.00131

Sierra, C. A. (2011). Temperature sensitivity of organic matter decomposition in the Arrhenius equation, some theoretical considerations. Biogeochemistry 108, 1-15. doi: 10.1007/s10533-011-9596-9

Sunagawa, S., Coelho, L. P., Chaffron, S., Kultima, J. R., Labadie, K., Salazar, G., et al. (2015). Structure and function of the global ocean microbiome. Science 348:1261359. doi: 10.1126/science.1261359

Tamburini, C., Boutrif, M., Garel, M., Colwell, R. R., and Deming, J. W. (2013). Prokaryotic responses to hydrostatic pressure in the ocean, a review. Environ. Micro. 15, 1262-1274. doi: 10.1111/1462-2920. 12084

Teira, E., Hernando-Morales, V., Cornejo-Castillo, F., Alonso-Sáez, L., Sarmento, H., Valencia-Vila, J., et al. (2015). Sample dilution and bacterial community composition influence empirical leucine-to-carbon conversion factors in surface waters of the world's oceans. Appl. Environ. Microbiol. 81, 8224-8232. doi: 10.1128/AEM.02454-15

Vázquez-Dominguez, E., Vaqué, D., and Gasol, J. M. (2007). Ocean warming enhances respiration and carbon demand of coastal microbial plankton. Glob. Change. Biol. 13, 1327-1334. doi: 10.1111/j.1365-2486.2007.01 377.x

Westrich, J. T., and Berner, R. A. (1988). The effect of temperature on rates of sulfate reduction in marine sediments. GeoMicrob. J. 6, 99-117. doi: 10.1080/01490458809377828

White, P. A., Kalff, J., Rasmussen, J. B., and Gasol, J. M. (1991). The effect of temperature and algal biomass on bacterial production and specific growth rate in freshwater and marine habitats. Microb. Ecol. 33, 99-118. doi: 10.1007/BF02539147

Yvon-Durocher, G., Caffrey, J. M., Cescatti, A., Dossena, M., del Giorgio, P., Gasol, J. M., et al. (2012). Reconciling the temperature dependence of respiration across timescales and ecosystem types. Nature 487, 472-476. doi: 10.1038 /nature 11205

Conflict of Interest Statement: The authors declare that the research was conducted in the absence of any commercial or financial relationships that could be construed as a potential conflict of interest.

Copyright (C) 2016 Lønborg, Cuevas, Reinthaler, Herndl, Gasol, Morán, Bates and Alvarez-Salgado. This is an open-access article distributed under the terms of the Creative Commons Attribution License (CC BY). The use, distribution or reproduction in other forums is permitted, provided the original author(s) or licensor are credited and that the original publication in this journal is cited, in accordance with accepted academic practice. No use, distribution or reproduction is permitted which does not comply with these terms. 